\title{
PLASTIC STRAIN MEASURMENTS OF DEEP DRAWN PART BY MEANS OF PHOTOGRAMMETRY
}

\section{Ing. Michal ČINÁK, Ing. Alexander SCHREK, PhD., Ing. Peter ŽITŇANSKÝ, PhD.}

Institute of technologies and materials, Pionierska 15, 83102 Bratislava, Faculty of Mechanical Engineering, Slovak University of Technology in Bratislava.

\begin{abstract}
Local strain is often evaluated by means of the deformation pattern of circles as they change, during the forming process, into ellipses. The surface with such deformed pattern is then evaluated by an optical measurement system. Automated optic evaluation requires high-priced equipment and thus, at the Institute of Technologies and materials, we have developed manual methods for strain evaluation. The digital photography method is effective but restricted only to planar strain areas. Multiple image stereo photogrammetry enables us to digitalize the surface of the part into a three-dimensional form, including the real texture colour of deformation pattern. Strain measurements of individual ellipse elements are executed exclusively on the virtual threedimensional model, without any restriction by the shape geometry of the surface.
\end{abstract}

KEYWORDS: Strain measurement, Stereo-photogrammetry,

\section{INTRODUCTION}

Measurements of strain distribution over an area of a formed part provides important information for the evaluation of the products quality, consideration of material formability in certain processes, and also verification of the simulation results of a forming process. Contactless optic measurement of strains in drawn parts is usually evaluated by means of pre-etched texture patterns that change during the forming process. There are many sophisticated devices and software able to automatically evaluate deformation of different textures and surfaces based on computer vision, digital image correlation, laser interferometry, whose precisions and resolutions are of high level but also require high financial resources too.

Manual strain measurement by means of microscope with a movable stand is a time consuming method and its resolution depends on the patterns element density. Circular elements

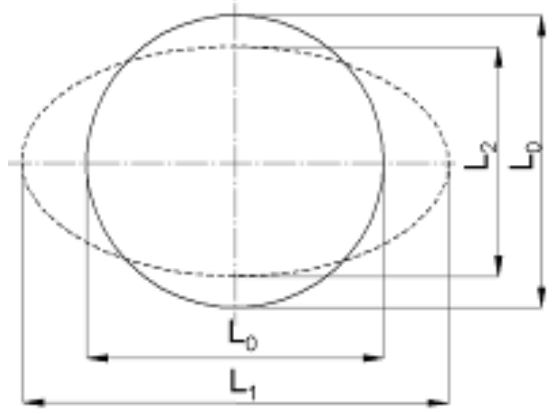

$$
\begin{aligned}
& \varphi_{1}=\ln \frac{\mathrm{L}_{1}}{\mathrm{~L}_{0}} \\
& \varphi_{2}=\ln \frac{\mathrm{L}_{2}}{\mathrm{~L}_{0}}
\end{aligned}
$$

Fig. 1: Strain calculation of circular element [1]

are strained into ellipses and their major and minor axes $\mathrm{L}_{1}, \mathrm{~L}_{2}$ determine the major and minor strain calculation $\varphi_{1}, \varphi_{2}$ according to the formulae in Fig. 1. 
SCIENTIFIC PROCEEDINGS 2011, Faculty of Mechanical Engineering, STU in Bratislava Vol. 19, 2011, pp. 112-118, DOI: 10.2478/v10228-011-0019-7

\section{ONE IMAGE CLOSE-RANGE PHOTOGRAMMETRY}

Instead of using microscope, it is more effective to use an indirect measurement method by means of high quality digital photography (Fig. 2), i.e. simple projective photogrammetric method. Photogrammetry is a widely used method in the industry. Its applications include measuring the optical strain and displacement, quality control, reverse engineering, robot calibration, space simulations and safety test analysis. It is an indirect physical measurement method that uses an object's photograph for its shape and dimensional reconstruction [3]. This simple one image method enables the in-plane measurement of the surface, that is perpendicular to the camera's axis. That is why we are searching for a method that would enable the measurement of deformation pattern in any point of the deep drawn part, without restrictions in shape geometry.

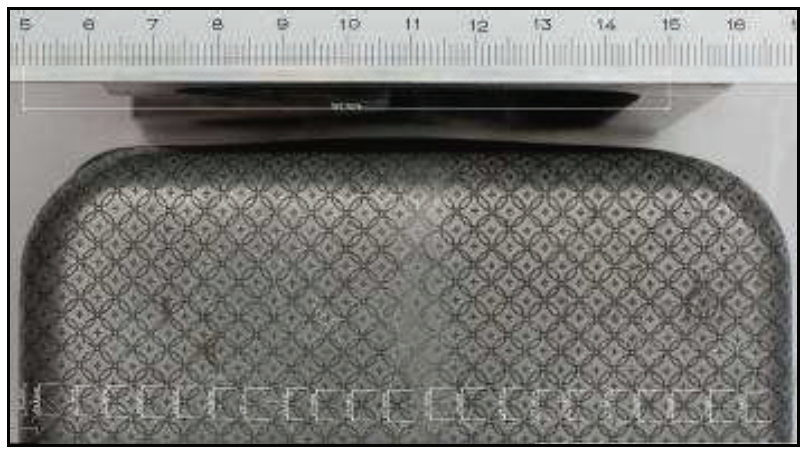

Fig. 2: Strain measurement in the bottom of the drawn part by means of photography [1]

\section{MULTIPLE IMAGE CLOSE-RANGE PHOTOGRAMMETRY}

Photogrammetric methods for surface measurement use at least two image orientations for determining the 3D coordinates of an object points [4]. In this case of multiple-image photogrammetry it is possible to create a sufficiently accurate model of the measured part with identical deformation pattern texture. Consequently, the measurement is not restricted only to planar region of the deep drawn part.

To create the model from photogrammetric images we used the PhotoModeler Scanner software from EOS Systems Inc. Stereo-couple of images is needed, and after their orientation the software can create the point cloud and 3D image of the scanned surface. As a prerequisite, the surface must provide sufficient textural information that enables detection and matching of homologous points [4]. Point coordinates are calculated by image correlation and collinear conditions. The principle is based on the theory that each pixel of the image has its own unique surrounding - pixel matrix in which by comparison of the position of the point on the second image is identified. The bigger the dimension of comparing matrix, the higher the probability of finding homologous points couple, but the longer computation of course [5].

\section{STEPS FOR CREATING THE MODEL OF THE MEASURED SURFACE:}

First of all, the camera must be calibrated to determine internal parameters of the images such as:

- $\quad$ main point coordinates

- focal length

- coefficients of radial and eccentric distortion. 
SCIENTIFIC PROCEEDINGS 2011, Faculty of Mechanical Engineering, STU in Bratislava Vol. 19, 2011, pp. 112-118, DOI: 10.2478/v10228-011-0019-7

For the calibration of semi metric camera, it is suitable to use laboratory calibration on a testing field that contains 60 to 100 spatially organized test points [6]. In the PhotoModeler Scanner software the camera calibration runs automatically by processing 8 images of the testing calibration grid that contain coded targets (Fig. 3).

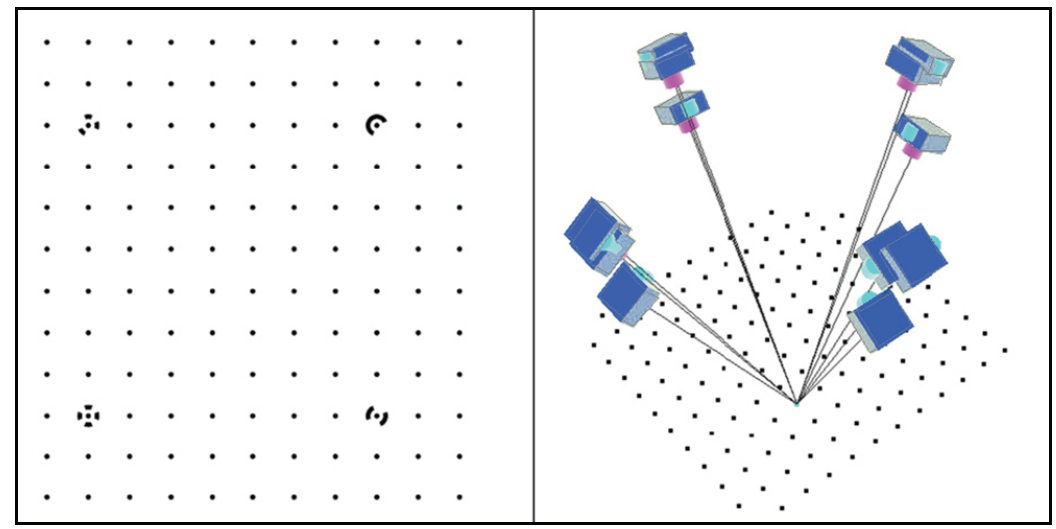

Fig. 3: Calibration grid and its image processing during automatic calibration [7].

Image for the photogrammetric scanning process must be made while keeping specific rules (Fig. 4) that result from the image correlation principles. Camera axis of the image couple should be slightly convergent $\left(15^{\circ}-30^{\circ}\right)$ and the proportion base/distance $(\mathrm{b} / \mathrm{h})$ should be in the range of $0,1-0,5$ which ensures good coverage. Ideal proportion is 0,25 . Noise and blur can cause problems in image correlation or even make it impossible. That is why we use the smallest ISO sensitivity and tripod. Same lighting in images is also important, without flash. For mutual referencing it is suitable to use coded targets [8].

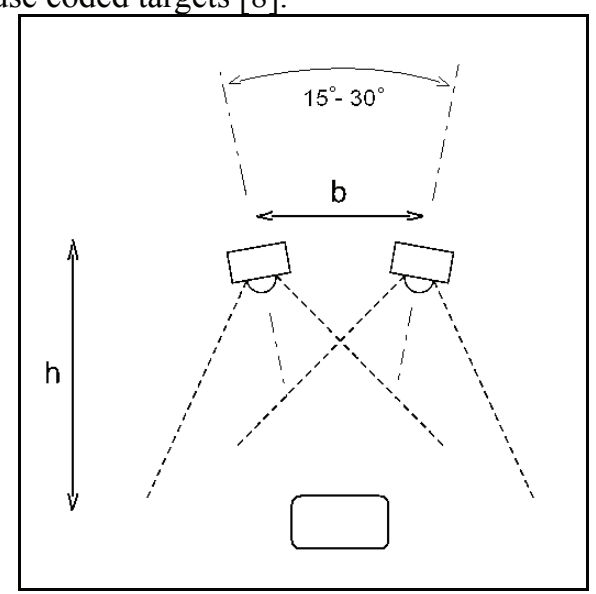

Fig. 4 Image-capture conditions

During the experiment we were using a semiprofessional digital camera: Canon 1000 D EF-S 18-55 with parameters in (Tab. 1.):

\begin{tabular}{|l|l}
\hline Focal length & $f=55 \mathrm{~mm}$
\end{tabular} 
SCIENTIFIC PROCEEDINGS 2011, Faculty of Mechanical Engineering, STU in Bratislava Vol. 19, 2011, pp. 112-118, DOI: 10.2478/v10228-011-0019-7

\begin{tabular}{|l|l|}
\hline CCD sensor dimensions & $22,2 \times 14,8 \mathrm{~mm} \quad(d \times v)$ \\
\hline Max. image resolution & $3888 \times 2592$ \\
\hline Number of pixels & $10.1 \mathrm{Mpix}$ \\
\hline
\end{tabular}

Tab.1: Parameters of digital camera Canon 1000D EF-S 18-55

The accuracy in determining the position of automatically marked points by convergent method is calculated according to the relation [2]:

$$
\sigma=M_{\mathrm{s}} P \sigma^{\prime}=\frac{\mathrm{h}}{\mathrm{f}} \frac{\mathrm{d}}{\mathrm{n}_{\mathrm{pix}}} \sigma^{\prime}=0.005 \mathrm{~mm}
$$

where:
$M_{s} \quad$ - image scale
$P \quad$ - pixel dimension on CCD sensor,
$\sigma^{\prime}=0,1$ pix $\quad$ - accuracy of determination of 3D coordinates,
$h=500 \mathrm{~mm} \quad$ - distance from object,
$n_{\text {pix }}=3888 \quad$ - number of pixels in a row of the sensor

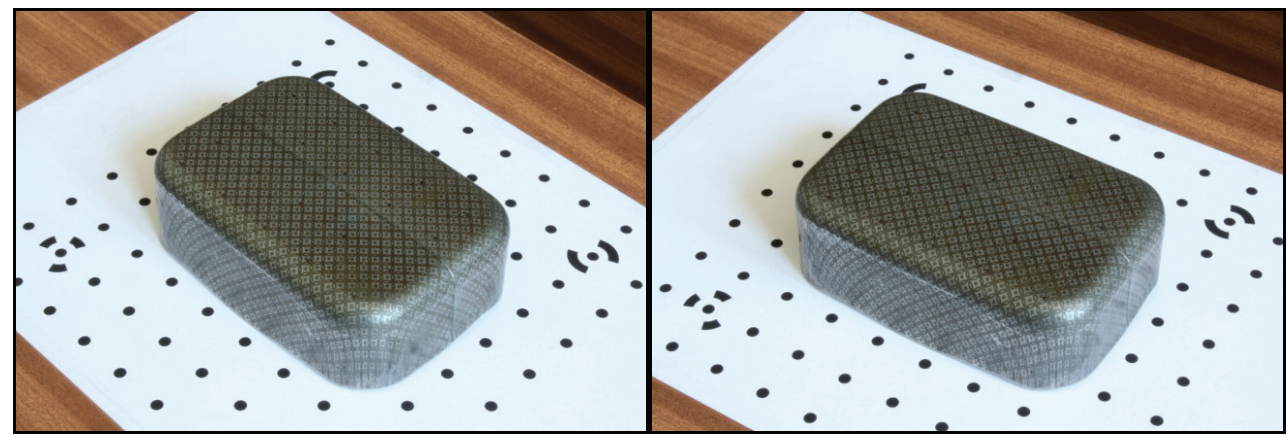

Fig. 5: Stereo-couple of images of drawn part

For processing we used a couple of images with an axes convergence of $15^{\circ}$. Centre position of the targets was determined by automatic sub-pixel mode that calculates the target centers with an accuracy of 0,1 pix. In the referencing mode we manually matched the pairs of homologous points and then the software orients the images and calculates 3-D coordinates of all points. Average error of all point corrections was 0,101 pix which is approximately 0,005 $\mathrm{mm}$. In the Dense Surface Modeling module a point cloud is generated on the principle of image correlation. Before final processing, idealization of the project, eliminate image distortion caused by camera lens, is required. Images are then resampled and we obtain black trimmed regions on each photograph (Fig. 6 a) [8]. By the "Trim boundary" function the region of image correlation can be selected. We can set up the parameters of calculation as follows:

- image couple

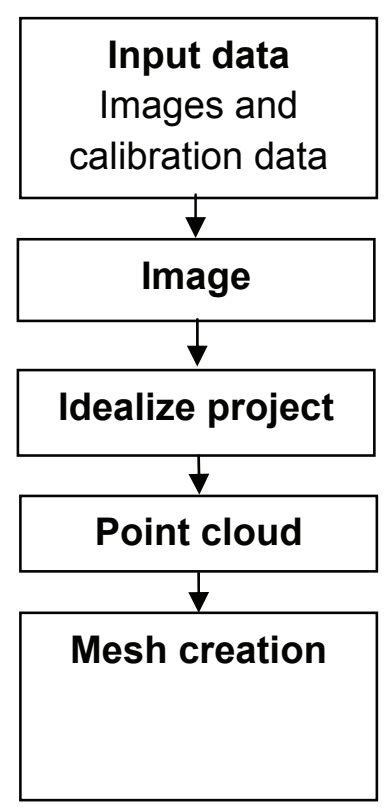


SCIENTIFIC PROCEEDINGS 2011, Faculty of Mechanical Engineering, STU in Bratislava Vol. 19, 2011, pp. 112-118, DOI: 10.2478/v10228-011-0019-7

- $\quad$ sampling rate

- depth range

- sub-pixel

- $\quad$ super-sampling factor

- matching region-radius

- texture type

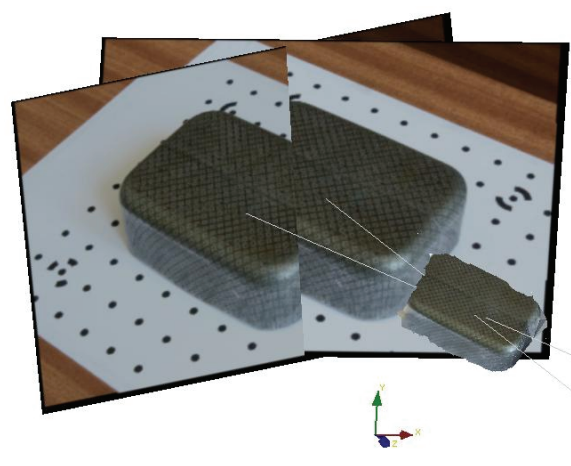

a)

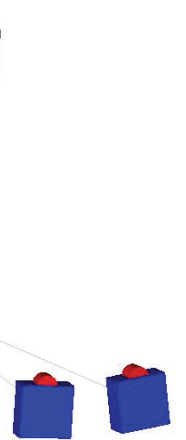

Fig. 6: a) Principle of stereo photogrammetry, b) 3D visualization of generated part surface

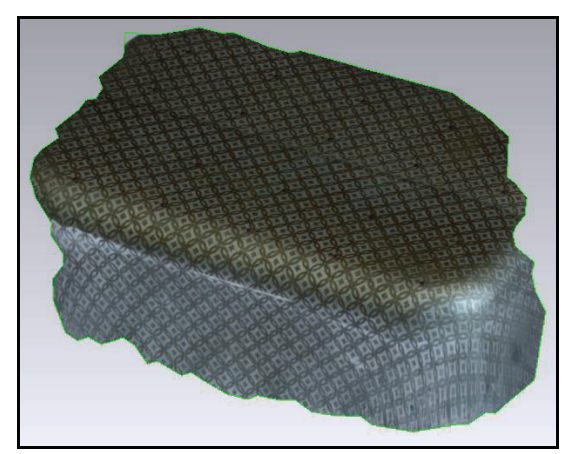

b)

\section{STRAIN MEASUREMENTS}

The result of image-correlation computing is the point-cloud and interpolated surfaces whose texture is from the image. In Fig. 6, b is the resulting surface of deep drawn part with texture. The surface is trimmed of regions where the software could not find homologous pixels by image correlation because of reflections from glossy metal surfaces. The surface is exportable into many formats that are widely used by current CAD-software. After model scaling it is possible to measure the elements of circular pattern. The measurement errors in the case of neglecting the surface curvature are shown in Fig. 7. The real length between points is $4,6 \%$ larger.

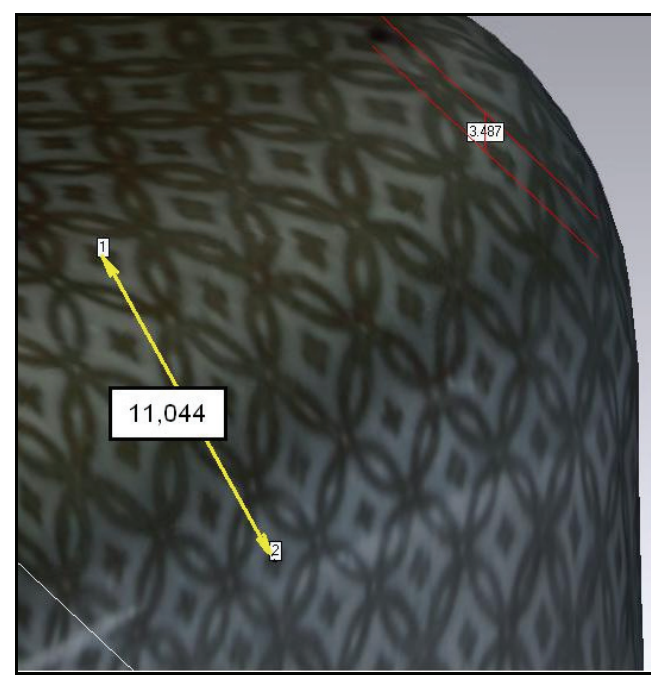

a)

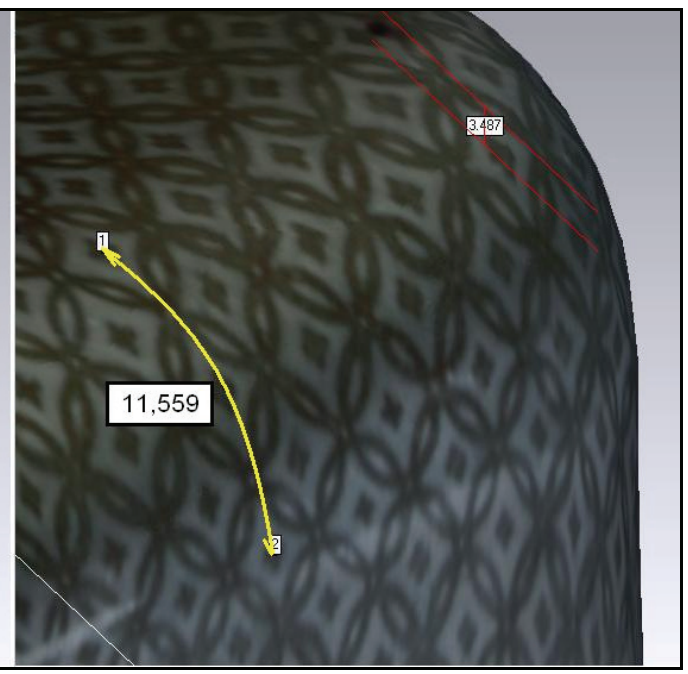

b) 
SCIENTIFIC PROCEEDINGS 2011, Faculty of Mechanical Engineering, STU in Bratislava Vol. 19, 2011, pp. 112-118, DOI: 10.2478/v10228-011-0019-7

Fig. 7: Deformation measurement on 3-D model, a) shortest distance, b) distance on surface

By this process, another circular specimen was modeled and measured (Fig. 8). To minimize the errors, we have manually referenced $\mathrm{m}$ points of the pattern (cross centers). Measuring elements in the small radius region shows the advantages of this method in comparison to conventional methods because the shape distortion does not influence the result.

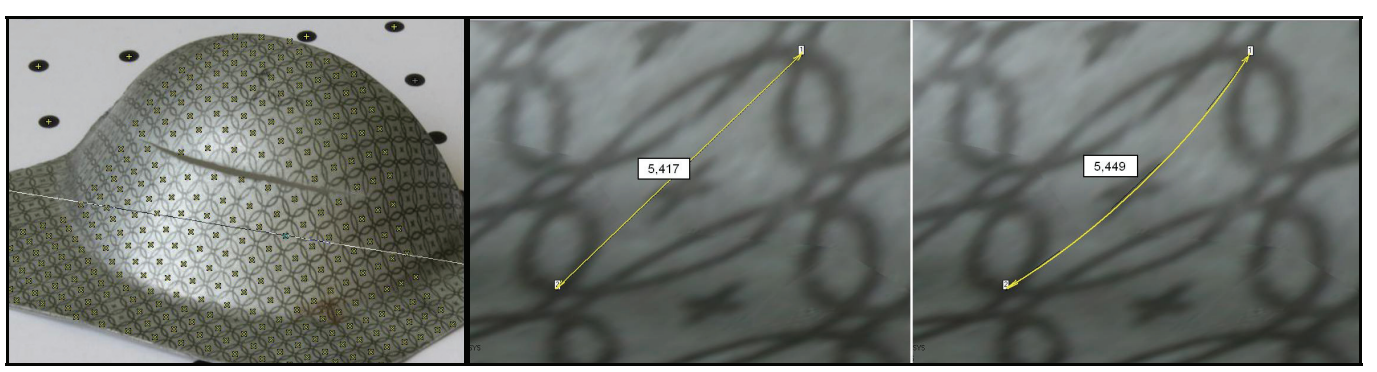

Fig. 8: Example of measuring the element of circular deformation pattern

\section{CONCLUSIONS}

By means of the presented photogrammetric method, we have expanded the possibilities of circular pattern measurement on to parts with complex surface geometry. In the range of the previously mentioned camera distance, this method is able to reconstruct the shape accurately within $0,005 \mathrm{~mm}$. Strain measurements depend on the digital quality of the texture. Referring to the aforementioned advantages it will be possible to apply this measurement method to more complex drawn parts of larger dimensions for their quality evaluation and for verification of the simulations results.

\section{REFERENCES}

[1] ŽITŇANSKÝ, P.: Simulácia tvárnenia súčiastok z plošných polotovarov novej generácie, Dizertačná práca, Ústav technológií a materiálov SjF STU Bratislava 2009.

[2] BARTOŠ, P. a kol.: Inžinierske aplikácie digitálnej blízkej fotogrametrie. Zborník prednášok „Progresívne technológie v inžinierskej geodézii“ Katedra geodézie SvF STU Bratislava 2006.

[3] FRAŠTIA, M.: Prednášky z predmetu Aplikovaná blízka fotogrametria. Bratislava, 2009.

[4] LUHMANN, T.: Close range photogrammetry for industrial applications, ISPRS Journal of Photogrammetry and Remote Sensing 65 (2010) 558-569

[5] PAVELKA, K., HODAČ, J.: Fotogrammetrie 3. Digitální metódy a laserové skenování. Skriptum. Česká technika - nakladatelství ČVUT, Praha, 2008, s. 67-69.

[6] FRAŠTIA, M.: Kalibrácia a testovanie digitálnych kamier pre aplikácie blízkej fotogrametrie. Edícia vedeckých prác. Zošit č. 52. Bratislava, STU v Bratislave, SvF 2008. ISBN 978-80-2272812-6. 
SCIENTIFIC PROCEEDINGS 2011, Faculty of Mechanical Engineering, STU in Bratislava Vol. 19, 2011, pp. 112-118, DOI: 10.2478/v10228-011-0019-7

[7] PhotoModeler 6 Help File

[8] BELIŠ, M., NEMČÍK, M.: Analysis of surface measurement by photogrammetric scanner, ŠVK Geodézia a kartografia 1. apríla 2009 